\title{
The direct Myc target Pim3 cooperates with other Pim kinases in supporting viability of Myc-induced B-cell lymphomas
}

\author{
Linus Plym Forshell ${ }^{1}$, Yongmei Li ${ }^{1,2,}$, Tacha Zi Plym Forshell ${ }^{1,}{ }^{*}$, Martina Rudelius ${ }^{3}$, \\ Lisa Nilsson ${ }^{1}$, Ulrich Keller ${ }^{4}$ and Jonas Nilsson ${ }^{1}$ \\ ${ }^{1}$ Department of Molecular Biology, Umeå University, Umeå, Sweden \\ ${ }^{2}$ Department of Medical Microbiology, Tianjin Medical University, Tianjin, People's Republic of China \\ ${ }^{3}$ Department of Pathology, Technical University of Munich, Munich, Germany \\ ${ }^{4}$ Department of Medicine, Technical University of Munich, Munich, Germany \\ * Denotes equal contribution
}

Correspondence to: Jonas Nilsson, email: jonas.nilsson@molbiol.umu.se

Keywords: cancer, lymphoma, oncogenes, C-Myc, Pim-3

Received: June 1, 2011, Accepted: June 2, 2011,

Published: June 5, 2011

Copyright: @ Forshell et al. This is an open-access article distributed under the terms of the Creative Commons Attribution License, which permits unrestricted use, distribution, and reproduction in any medium, provided the original author and source are credited.

\section{ABSTRACT:}

The Pim kinases are weak oncogenes. However, when co-expressed with a strong oncogene, such as c-Myc, Pim kinases potentiate the oncogenic effect resulting in an acceleration of tumorigenesis. In this study we show that the least studied Pim kinase, Pim-3, is encoded by a gene directly regulated by c-Myc via binding to one of the conserved E-boxes within the Pim3 gene. Accordingly, lymphomas arising in Myc-transgenic mice and Burkitt lymphoma cell lines exhibit elevated levels of Pim-3. Interestingly, inhibition of Pim kinases by a novel pan-Pim kinase inhibitor, Pimi, in Myc-induced lymphoma results in cell death that appears independent of caspases. The data indicate that Pim kinase inhibition could be a viable treatment strategy in certain human lymphomas that rely on Pim-3 kinase expression.

\section{INTRODUCTION}

Tumorigenesis is a multistep process where several acquired genetic alterations, or hallmarks, occur leading to transformation of a cell [1]. c-Myc is a transcription factor with more than 1000 target genes (www.myccancergene. org), many of which directly impinge on the hallmarks of cancer. Therefore, Myc expression is often selected for during various steps in the genesis of many types of human cancer. To avoid transformation, normal cells can respond to Myc overexpression by undergoing apoptosis or senescence $[2,3]$. Thus, for Myc overexpression to drive transformation additional genetic alterations affecting apoptotic signaling are required [4], thereby allowing the state of genomic instability that facilitates the required accumulation of mutations.

The Pim kinase family is a group of three serine/ threonine kinases encoded by genes that were identified as hotspots for proviral integration of Moloney murine leukemia virus (Pim) in retrovirus-induced lymphomas [5]. The three kinases, Pim-1, Pim-2 and Pim-3, are considered weakly oncogenic when expressed as transgenes [6-8]. However, when co-expressed with Myc they strongly accelerate Myc-driven lymphomagenesis [6, 9-11]. The Pim kinase genes are located on different chromosomes but they encode proteins with similar sizes and with a high degree of homology [12].

The Pim kinases phosphorylate a wide variety of cellular targets involved in regulating the cell cycle, including cyclin-dependent kinase inhibitors p21 and p27 [13-15], cell cycle proteins such as CDC25A and CDC25C [16, 17]and suppressors of cytokine signaling SOCS1 and SOCS3 $[18,19]$. Moreover Pim kinases also phosphorylate proteins involved in translation such as eIF4B [20] and 4EBP1 [21], pro-apoptotic Bcl-2 family member Bad [21-24] and transcriptional regulators such as Myc [25], Myb [26], RUNX1 and RUNX3 [27]. Recently it was shown that Pim-1 can bind the Myc-Max complex and so get recruited to E-boxes from where Pim-1 can phosphorylate serine 10 on histone H3 [28]. This phosphorylation regulates up to $20 \%$ of the Myc transcriptional targets, some of which are needed for Myc driven transformation. It is not known whether all of the above-described functions represent separable functions 
of the different Pim family members or if significant redundancies exist. Nevertheless, single knockout mice do not have any overt phenotype whereas triple Pim $1^{-1-}$ ;Pim2 $2^{-/-}$; Pim $3^{-/-}$knockout mice are smaller and exhibit a small defect in lymphomcyte stimulation capacity [12].

Despite the strong genetic links between Myc and Pim kinases emanating from experimental models of cancer, it is not clearly established whether or not activation of Pim kinases occurs spontaneously in Mycinduced lymphomas. To address this we analyzed B-cell tumors that arose in $\lambda-M y c$ transgenic mice [29], which express c-Myc under the control of the immunoglobulin

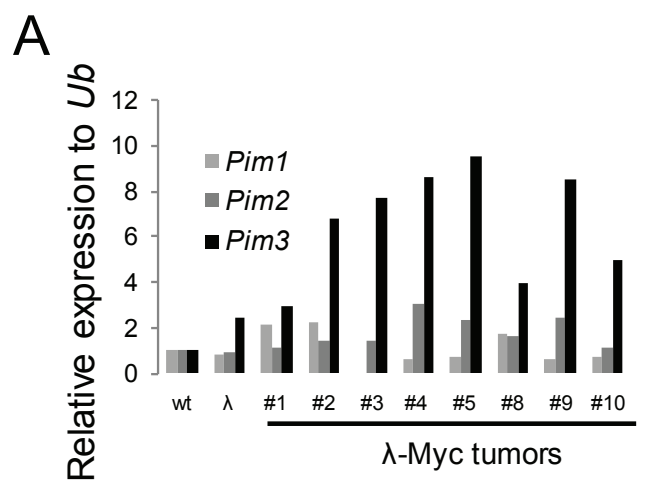

B
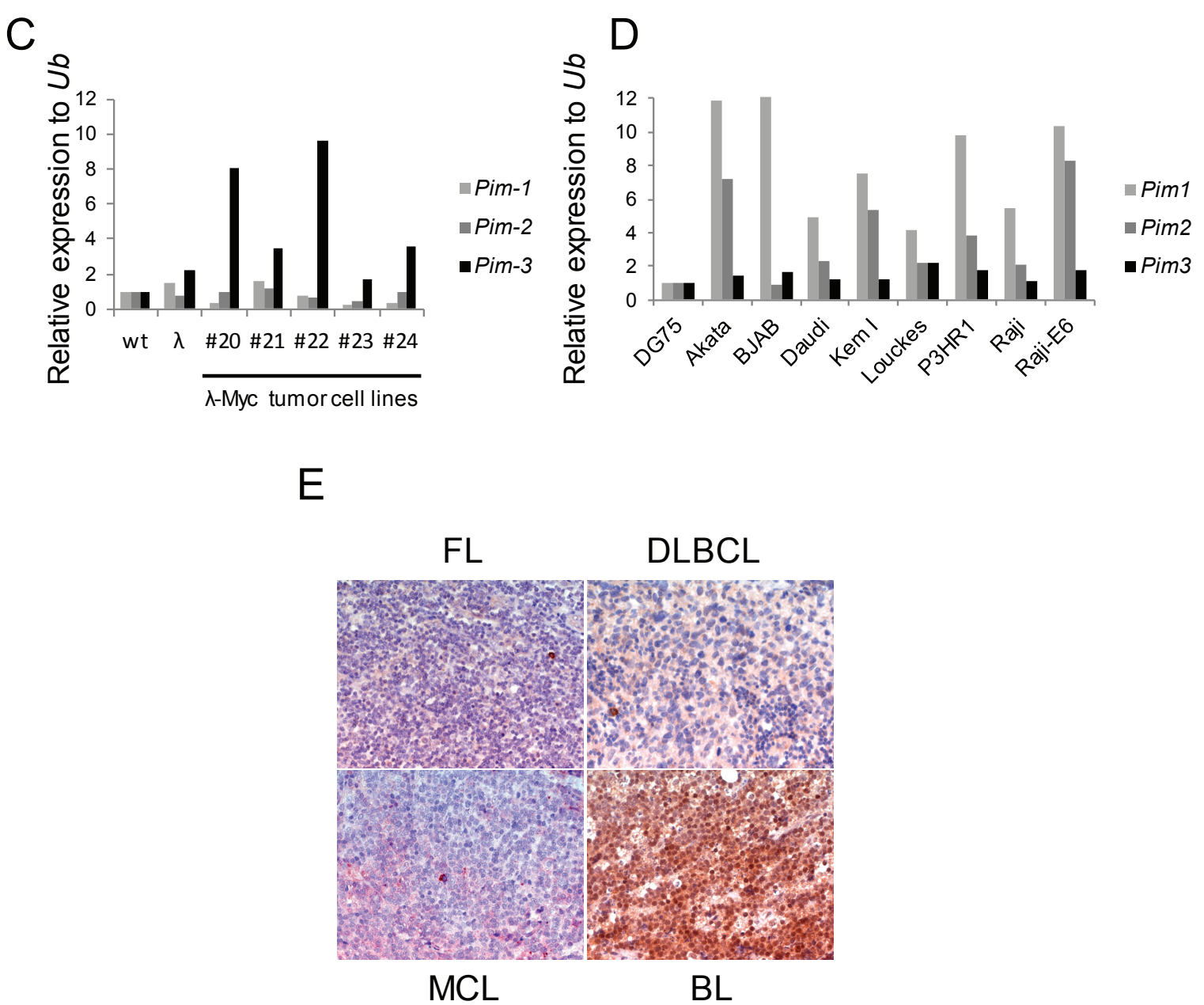

Figure 1: Pim-3 expression is elevated in mouse and human lymphoma tissue. (A) Quantitative reverse transcription PCR (qRT-PCR) analysis of Pim kinase expression in B cells from wildtype and precancerous $\lambda$-Myc transgenic mice ( $\lambda$ ), and in lymphomas harvested from $\lambda$-Myc transgenic mice. Pim kinase levels were normalized to that of ubiquitin (Ub) (B) Western blot analysis of Pim-3 kinase (using an antibody from Cell signaling) in same material as analyzed by qRT-PCR. (C) qRT-PCR analysis of Pim-kinase expression in cell lines established from $\lambda-M y c$ and E $\mu-M y c$ transgenic mice. (D) qRT-PCR analysis of Pim-kinase expression in Human Burkitt lymphoma cell lines. The expression levels are relative to that of one of the cell lines, DG75. (E) Immunohistochemistry analysis of Pim-3 expression in various lymphomas from patients. The antibody was from Abcam. 
A
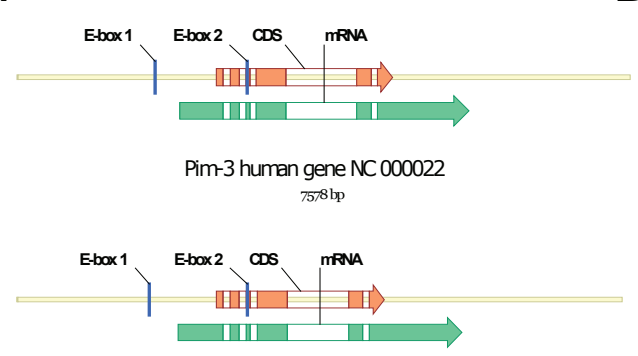

Pim3 mouse gene NC 00081 $7533 \mathrm{bp}$

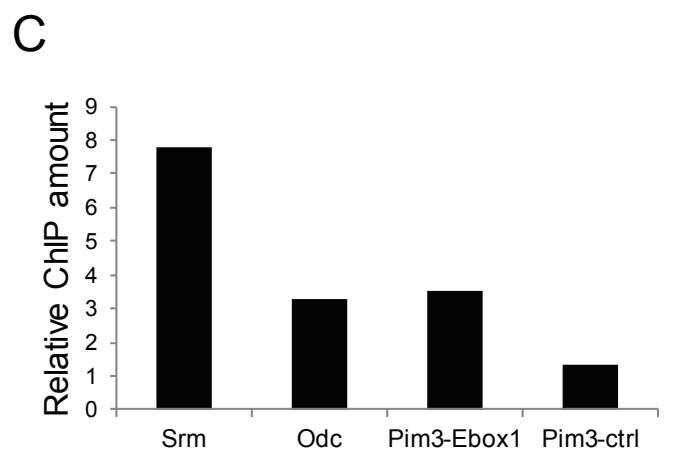

B

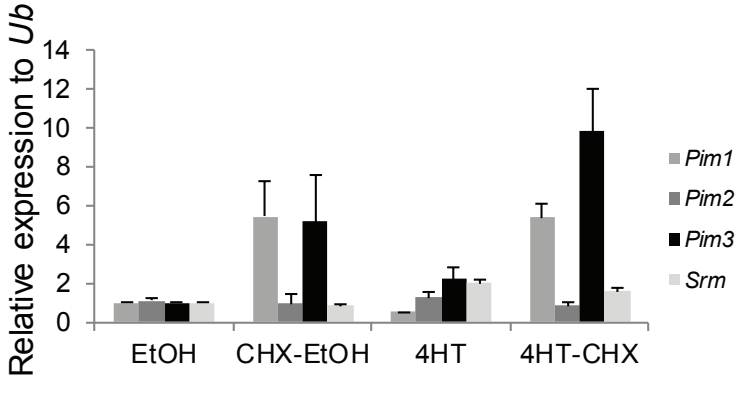

D

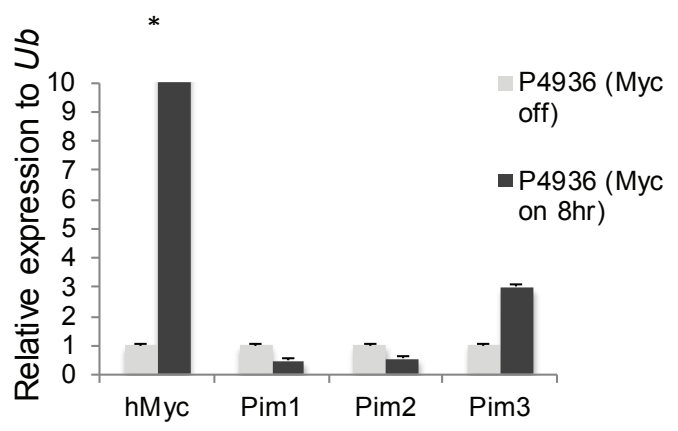

E

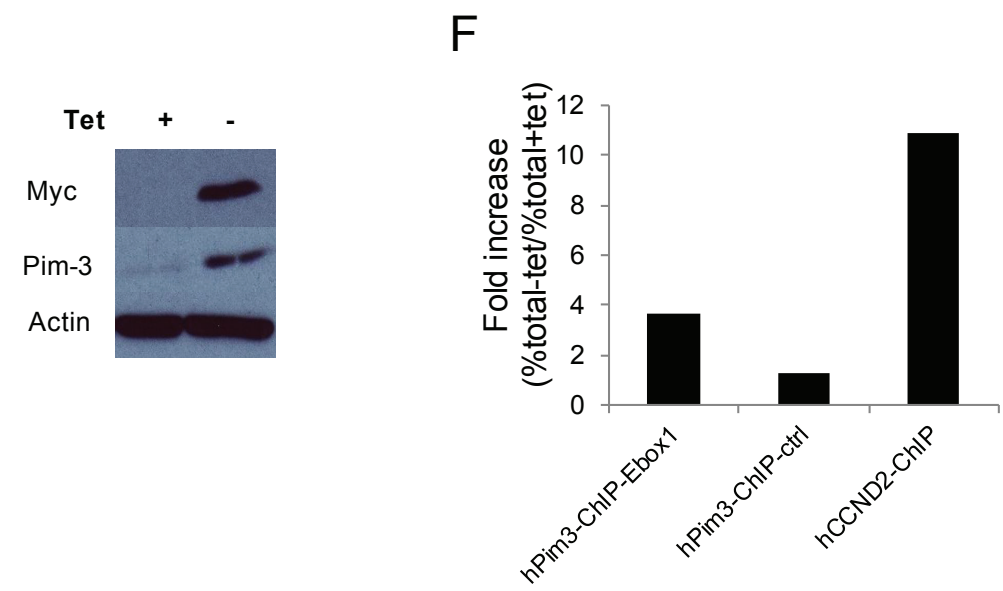

Figure 2: The Pim3 gene has evolutionary conserved E-boxes, which mediate Myc-regulated transcription. (A) Schematic representation of mouse and human Pim3 loci, which contain two evolutionarily conserved E-boxes (CACGTG). (B) NIH 3T3 fibroblasts carrying a MycER construct were treated with the estrogen receptor (ER) agonist 4-hydroxytamoxifen (4-HT) with or without the translation inhibitor cycloheximide (CHX) for $4 \mathrm{~h}$ and were then harvested for qRT-PCR analysis of Pim expression. Srm, a Myc target gene with five E-boxes, was used as a positive control. (C) Chromatin immunoprecipitation (ChIP) assay was run on $\lambda 820$ cells using a Myc antibody to immunoprecipitate the E-box regions. Immunoprecipitated chromatin was subsequently analyzed by qPCR utilizing primers directed against E-box regions of the Myc target genes Srm and Odc but also against the E-box1 in the Pim3 locus. As a negative control primers designed not to recognize the Pim 3 gene (Pim3-ctrl) were used. Percent total chromatin immunoprecipitated was calculated using the equation \% total $=2$ (Ct input - Ct ChlP) $\mathrm{x} \%$ input and was presented as "Relative fold increase" calculated accordingly, $\%$ total sample / \% total negative control. The negative control value was generated by immunoprecipitation using normal rabbit IgG. Shown is one of two independent experiments yielding similar results. (D) The human BL cell line P493-6 carrying a tetracycline (tetoff) regulatable system for Myc expression was cultured with $0.1 \mu \mathrm{g} / \mathrm{ml}$ tetracycline (tet) or without tet for 8 hours, after which cells were harvested for qRT-PCR analysis of Pim and Myc transcripts (E) P493-6 cells from the same experiment were also harvested for western blot analysis of Pim-3 and Myc protein expression. (F) P493-6 cells were cultured with tetracycline for 72 hours and then divided into two subcultures, one with tetracycline (myc off) and one without (myc on), and were cultured for another 8 hours before being harvested for ChIP analysis. Chromatin was immunoprecipitated using a Myc antibody and the qPCR was run with primers directed against the PIM3 E-box1, primers not recognizing the PIM3 gene as negative controls, and primers against CCND2 as a positive control. Percent total chromatin immunoprecipitated was calculated as described above. Data were presented as "Fold increase (\%total - tet / \%total+tet)". Shown is one of two independent experiments yielding similar results. 
1 enhancer. To our surprise we find that the most highly expressed Pim kinase in these lymphomas is Pim3, and that Pim3 is a Myc target gene. These data may partly explain why proviral activation of Pim 1 and Pim2 in E $\mu-M y c$ mice occurs most frequently - Pim3 is already activated by Myc. Importantly, we also show that inhibition of Pim kinases induces cell death of Mycinduced lymphomas.

\section{RESULTS}

\section{Pim-3 kinase protein levels are elevated in Myc over expressing tumors}

Although considered weak oncogenes, all Pim kinase family members have been shown to strongly potentiate Myc driven tumorigenesis as proviral insertion targets or transgenes [6, 9-11]. Although these landmark studies established a genetic link between Myc and Pim kinases, they did not address whether this synergy could be established spontaneously in a reciprocal manner. To partly address this we analyzed B-cell tumors from $\lambda-M y c$ transgenic mice for Pim kinase mRNA expression levels. Quantitative reverse transcriptase PCR (qRT-PCR) showed that elevated RNA levels of Pim 1 and Pim 2 could be observed in some tumors but that Pim 3 was the only Pim kinase family member with significantly elevated mRNA levels in all tumors as compared to wildtype B cells (Figure 1A). Interestingly, elevated Pim 3 mRNA and Pim-3 protein were seen not only in tumors but also in $\mathrm{B}$ cells harvested from 4-6 week old precancerous mice with no signs of lymphoma (Figure 1A and $1 \mathrm{~B}$ ). Moreover, tumor cell lines established from $\lambda-M y c$ and $\mathrm{E} \mu-M y c$ transgenic mouse B cell tumors still exhibited elevated mRNA levels of Pim3, suggesting the importance of maintaining expression even in conditions of surplus growth factors (Figure 1C). To analyze which of the Pim kinases were expressed in human lymphomas, we analyzed a set of human Burkitt lymphoma (BL) cell lines by qRT-PCR. When Pim kinase expression in the human BL cell line DG75 was set to 1, it appeared as if Pim1 and Pim 2 mRNA is elevated in all the BL cells (Figure 1D). However, when analyzing the $\mathrm{Ct}$ values it became obvious that Pim 3 was the more abundant Pim transcript because a signal was obtained at cycle 21 , as opposed to cycle 23 or higher for Pim 1 and Pim 2 mRNAs. Moreover, immunohistochemistry analysis of Pim-3 expression in mantle cell lymphoma (MCL), follicular lymphoma (FL), diffuse large cell B-cell lymphoma (DLCBL) and $\mathrm{BL}$ showed that BL is the lymphoma-type that exhibits the highest Pim-3 expression (Figure 1E). Taken together, the data indicate that Pim-3 is the main Pim kinase overexpressed in Myc-induced lymphomas from mice and patients whereas Pim-1 and Pim-2 are more sporadically overexpressed.

\section{Pim3 is a direct Myc transcriptional target}

Myc transcription is mediated through $\mathrm{E}$ box sequences, most often CACGTG [30-37]. To investigate if the high levels of Pim-3 in Myc-expressing cells and tumors were due to a direct induction of transcription, we first analyzed the nucleotide sequence of the Pim 3 locus and found that it contains two potential E-boxes, which were conserved in mice and man (Figure 2A). We then infected NIH3T3 fibroblasts with a retrovirus expressing Myc-ER, an inducible form of Myc that can be activated by adding the estrogen analog 4-hydroxytamoxifen (4-HT) to the culture medium. Addition of 4-HT, with or without the translation inhibitor cycloheximide, showed that the mRNA of the direct Myc target Srm could be induced 2-fold even when translation was inhibited, as could Pim3 mRNA (Figure 2B). Because Pim3 also was induced by cycloheximide, which complicates interpretation of these types of experiments, we analyzed whether Myc binds the E-boxes of the Pim3 locus by performing chromatin immunoprecipitation assay (ChIP) on formaldehyde cross-linked DNA from a $\lambda-M y c$ transgenic mouse B-cell lymphoma cell line, $\lambda 820$, established in our laboratory [38]. Indeed, when ChIP was performed using primers designed to flank E-box 1 of Pim3, the signal obtained was comparable to that of the signal obtained with primers against $\mathrm{Srm}$ and $\mathrm{Odc}$ (Figure 2C), two confirmed Myc transcriptional targets $[39,40]$. Primers against a sequence one kb downstream of the Pim 3 gene was used as negative control, and yielded signals 3-7 times weaker. To assess if Myc directly regulates PIM3 in human cells we used the P493-6 lymphoma cell line, which has a tetracycline (Tet) regulatable Myc cassette, which is silent in the presence of tetracycline [41]. P493-6 cells were incubated 72 hours in the presence of tetracycline (Myc off) after which they were split in two cell culture flasks, one culture with tetracycline (Myc off) and one culture without tetracycline (Myc on). The two cultures were then incubated for 8 hours, after which cells were harvested for mRNA, protein and ChIP analysis. We ran a qRT-PCR on mRNA harvested from these samples to measure the PIM levels with and without Myc expression. In accordance with the mouse results expression of Pim-3 kinase, but not Pim-1 or Pim-2, was induced by Myc activation at the transcriptional (Figure 2D) and translational level (Figure 2E). Moreover, ChIP experiments performed using a Myc antibody showed that the PIM3 E-box 1 was immunoprecipitated from the same P493-6 cell preparation, although to a lesser extent than the Myc target gene Cyclin D2 (CCND2) [42-44] (Figure $2 \mathrm{~F}$ ). Taken together, our results confirm that E-box 1 in the PIM3 locus is a functional target of Myc-mediated transcription in both human and mouse lymphoma cells. 

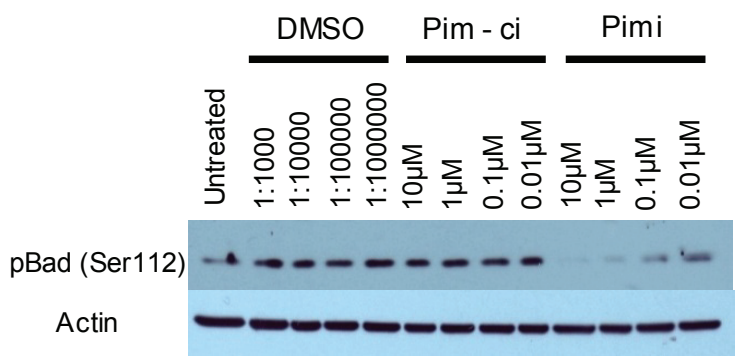

Actin

C
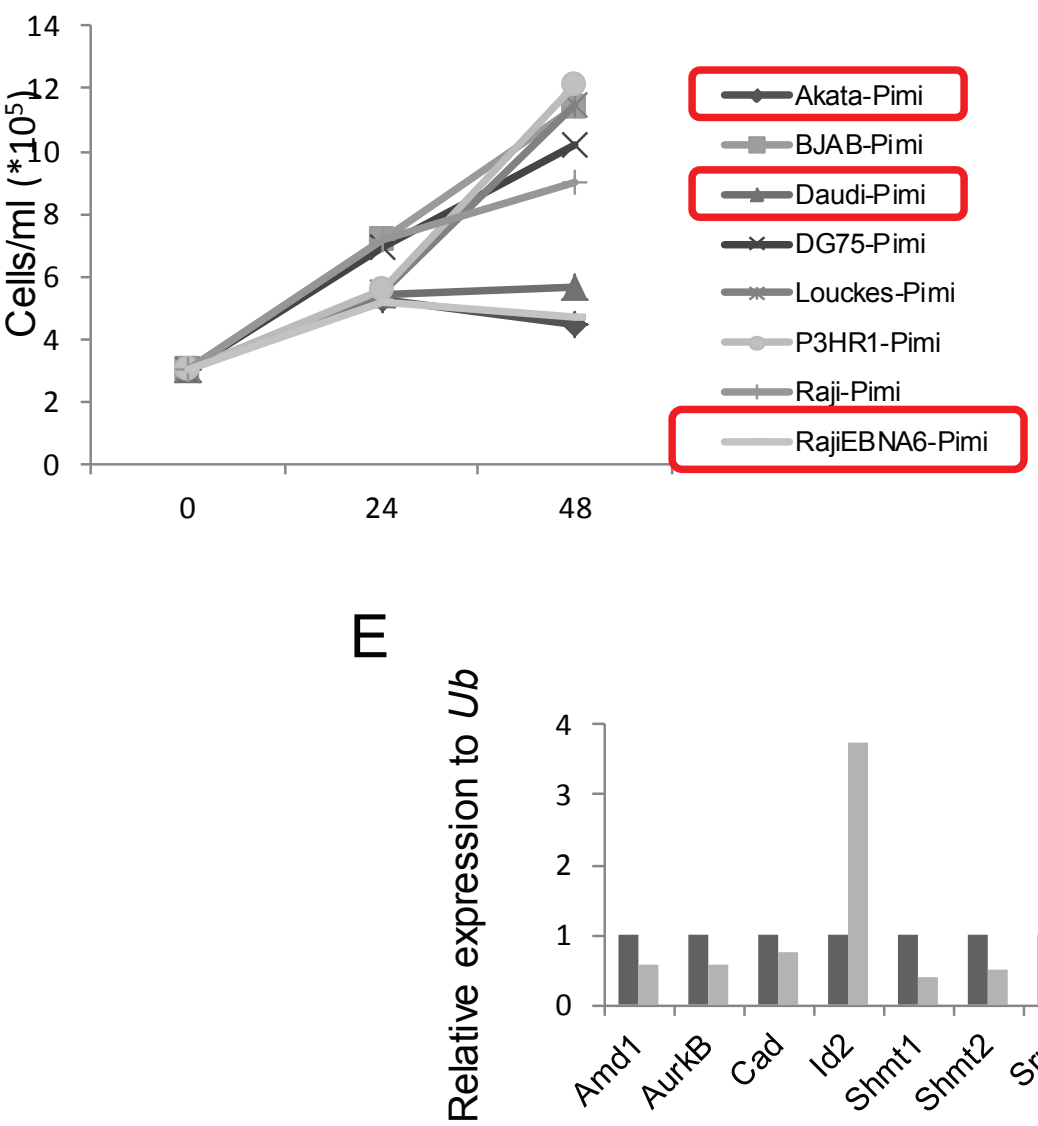

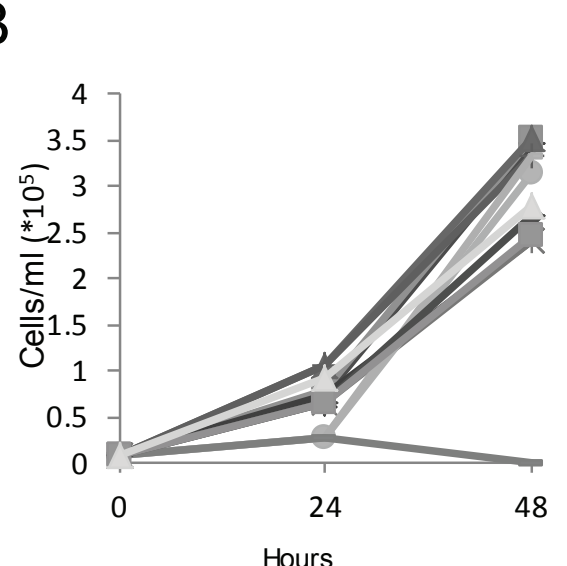

$\longrightarrow$ DMSO 1:1000
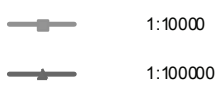

1:1000000
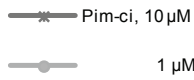

$\square$
$\longrightarrow$

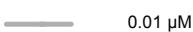

$\longrightarrow$ Pimi, $10 \mu \mathrm{M}$

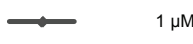

$\longrightarrow \quad 0.1 \mu \mathrm{M}$

$0.01 \mu \mathrm{M}$

D

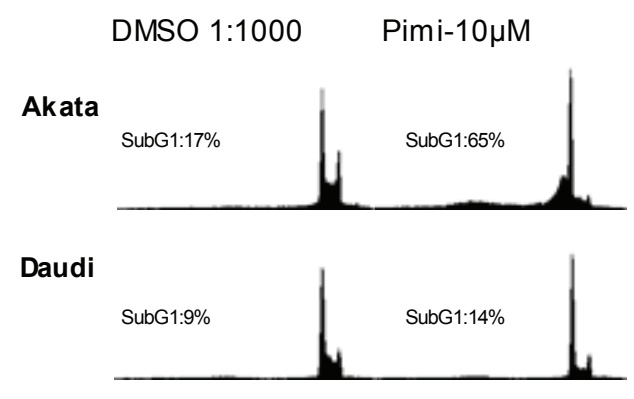

Raji-EBNA6

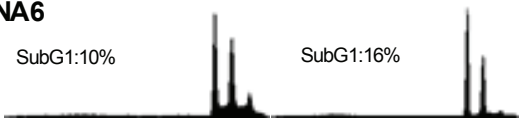

DMSO1:1000

- Pimi, $10 \mu \mathrm{M}$

Figure 3: Inhibition of Pim kinases leads to de-phosphorylation of the pro-apoptotic protein Bad on serine 112 and induction of cell death. (A) E $\mu 239$ cells were cultured for 4 hours in the presence of the indicated concentrations of DMSO, Pim-ci or the Pim inhibitor Pimi, after which cells were harvested for western blot analysis of Bad serine 112 phosphorylation. B) E $\mu 239$ cells were cultured in the presence of different concentrations of the indicated drugs and counted using trypan blue dye exclusion. C) Burkitt Lymphoma cell lines were cultured in the presence of $10 \mu \mathrm{M}$ Pimi or DMSO (not shown) for 24 and 48 hours. At each time point aliquots of cells were taken for cell counting (by trypan blue dye exclusion) to monitor cell growth. D) At the indicated time points aliquots of cells were stained with propidium iodide and scored for the ratio of cells having less than a diploid DNA content ( $<2$ ), Sub G1, by FACS analysis. E) RNA from E $\mu 239$ cells cultured for 24 hours in the presence of $10 \mu \mathrm{M}$ Pimi was harvested and analyzed by qRT-PCR for expression of the Myc transcriptional target genes, Amd1, Aurkb, Cad, Id2, Shmt1, Shmt2 and Srm. All values were normalized to that of the control primers, ubiquitin $(U b)$ run on the same sample. 


\section{The Pim kinase inhibitor Pimi hampers cellular proliferation and causes a reduction in Myc regulated transcripts}

Pim kinase expression has been associated with poor outcome in several different tumor types [4558] and chemoresistance have been seen in tumor cells overexpressing the Pim kinases [59-62]. This has inspired efforts to inhibit the Pim kinases as a cancer treatment. Since the triple knockout Pim kinase mice are viable and fertile, this suggests that inhibition of the Pim kinase family could be possible without severe side effects [12]. To test this notion we obtained a specific pan-Pim kinase inhibitor (Compound 14j [63] [A953864.1] or from now on Pimi) generated by Abbott Laboratories (Abbott Park, IL). This inhibitor exhibits low nanomolar activity against Pim-3, Pim-1 and Pim-2 (0.5 nM, 2 nM, 3 nM, respectively) and shows high degree of selectivity for Pim kinases (personal communication, Dr. Joel Leverson, Abbott Laboratories). To investigate if this inhibitor hits the expected targets, Pim kinases, and exhibits antiproliferative activity in Myc-induced lymphomas, we treated the mouse B-cell lymphoma cell lines E $\mu 239$ and $\lambda 820$ with Pimi and Pim-ci, a 1000-fold less potent Pim inhibitor from the same chemical series. As seen in Figure $3 \mathrm{~A}$, Western Blot analysis revealed that phosphorylation of the pro-apoptotic BH3-only Bcl-2 family member Bad on Ser112, which is believed to be a specific Pim kinase site, started to become decreased at $10 \mathrm{nM}$ and was abolished in cells treated for $8 \mathrm{~h}$ with $10 \mu \mathrm{M}$ Pimi, whereas Pim-ci did not affect phosphorylation. Moreover, measurement of incorporation of ${ }^{3} \mathrm{H}$-thymidine following $48 \mathrm{~h}$ of treatment with $10 \mathrm{nM}$ to $10 \mu \mathrm{M}$ Pimi demonstrated an EC50 of $2.6 \mu \mathrm{M}$ or $6 \mu \mathrm{M}$ for E $\mu 239$ and $\lambda 820$ cells, respectively (not shown). Since Pim-ci and the vehicle, DMSO, did not exert any anti-proliferative effects when added in the same relative quantities, we did not calculate EC50s for them.

To gain insight into the anti-proliferative effect of Pimi we generated growth curves on B cell lymphoma lines from mice and BL patients. Much like what was suggested from the ${ }^{3} \mathrm{H}$-thymidine incorporation assay, E $\mu 239$ cells were sensitive to $10 \mu \mathrm{M}$ Pimi, manifest as both slower growth and induction of cell death (Figure 3B). Surprisingly however, the anti-proliferative effect was only observed in a few human BL cell lines and growth curves and DNA histograms from FACS analysis of propidium iodide-labeled samples of the cell lines showed that Pimi was cytotoxic in Akata cells but only cytostatic in Daudi and Raji-EBNA6 cells (Figure 3C and 3D).

Pim-1 has been reported to facilitate transcriptional activation of $20 \%$ of Myc transcriptional targets through phosphorylation of Serine 10 on histone H3 (H3S10) [28]. The phosphorylation is mediated by Pim-1 interacting with Myc in the transcriptional active Myc-Max dimer, thus recruiting Pim-1 to E-boxes of active transcription. Since inhibition of Myc signaling in Myc-driven tumors can lead to growth arrest, senescence and cell death we entertained the idea that the observed effect of Pimi could be mediated by inhibition of Myc function. We therefore treated the mouse B cell lymphoma cell line E $\mu 239$ with $10 \mu \mathrm{M}$ Pimi for 24 hours, harvested mRNA and analyzed it using qRT-PCR for the Myc regulated genes Amd1 [39] , Aurkb [64], Cad [65], Shmt1, Shmt2 [66] and Srm [39]. Interestingly, several of the Myc-regulated target genes were down-regulated in Pimi-treated cells compared to DMSO controls (Figure 3E). On the other hand, expression of the disputed Myc target gene $I d 2$ [67, 68], was induced by Pimi.

\section{Pimi treatment induces Caspase-3 independent cell death}

Phosphorylation of Bad by Akt or Pim kinases renders this protein inactive as an inducer of apoptotic cell death. Since Pimi blocked Bad phosphorylation and since we observed cells with a sub-G1 DNA content in Pimi-treated cells, we wanted to investigate if the cells died by classical caspase-dependent apoptosis. Immunofluorescense on cells treated with Pimi for 24 and 48 hours with antibodies directed against the cleaved form of the death effector caspase- 3 showed marked increase in caspase-3 positive cells in Pimi-treated cells (Figure 4A). This was confirmed by FACS analysis on the same cells run in parallel. To define which phase of the cell cycle Pimi-treated cells died in, we performed a FACS analysis of fixed cells labeled with an antibody targeting cleaved caspase-3. Co-staining of DNA using 7-aminoactinomycin $\mathrm{D}$ (7-AAD) enabled us to analyze how caspase-3 positive cells were distributed in the cell cycle. As shown in Figure 4B, Pimi treatment led to caspase-3 activation in the $\mathrm{G} 2 / \mathrm{M}$ phase (region 4) and in cells with hyperdiploid DNA content ( $>4 n$, region 5), suggesting that cells were undergoing death because of a problem in mitosis. To test whether Pimi-induced cell death is caspase-dependent, the pan-caspase inhibitor QVD-OPH was used together with Pimi. Immunofluorescense and FACS analyses showed that QVD-OPH reduces the intensity of caspase-3 staining but does not block Pimi-activated cell death (Figure 4C). These data indicate that inhibition of Pim kinases either results in caspase-independent cell death or that the caspase inhibition required to block death is not pharmacologically achievable.

\section{DISCUSSION}

Here we show that the Pim 3 gene contains conserved 
E-boxes, one of which is bound by Myc, resulting in induction of transcription. This is the first time Myc has been implicated in regulation of a Pim kinase family member and it explains the high levels of Pim-3 found in Myc overexpressing mouse B cell lymphomas and human BL. It may also explain why Pim1 and Pim 2 are more frequently trapped by proviral insertions of retroviruses in Myc-transgenic mice and why these two genes need to be deleted in order to see selection for Pim3 trapping [9]. This in turn indicates that Pim-1 and Pim-2 kinases have non-redundant functions when expressed at normal levels but that they can be replaced by massive overexpression of Pim-3. Taken together these data indicate that the

A
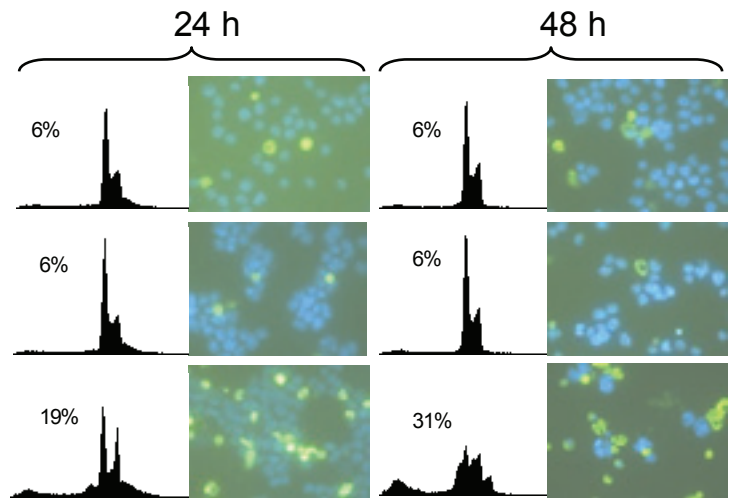

Pim - ci,10 $\mu \mathrm{M}$

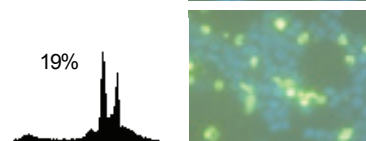

Cleaved caspase-3

Cleaved

caspase-3
DMSO 1:1000

Pimi, $10 \mu \mathrm{M}$ best rationale for developing Pim kinase inhibitors is to generate pan-inhibitors of all three family members, especially since triple knockout Pim kinase mice are viable.

Regulation of the Pim kinase family has focused mostly on Pim-1 and Pim-2, which are regulated by the Jak/STAT-pathway and by NfkB [6, 10, 69-75]. Significantly less is known about how Pim-3 expression is regulated, albeit one report shows that Pim-3 can be regulated by the Ets family of transcription factors in NIH 3T3 and human Ewing's sarcoma cells [76]. Later studies showed that Pim-3 is activated by the Ets- 1 transcription factor in pancreatic cancer cells [77]. Considering that

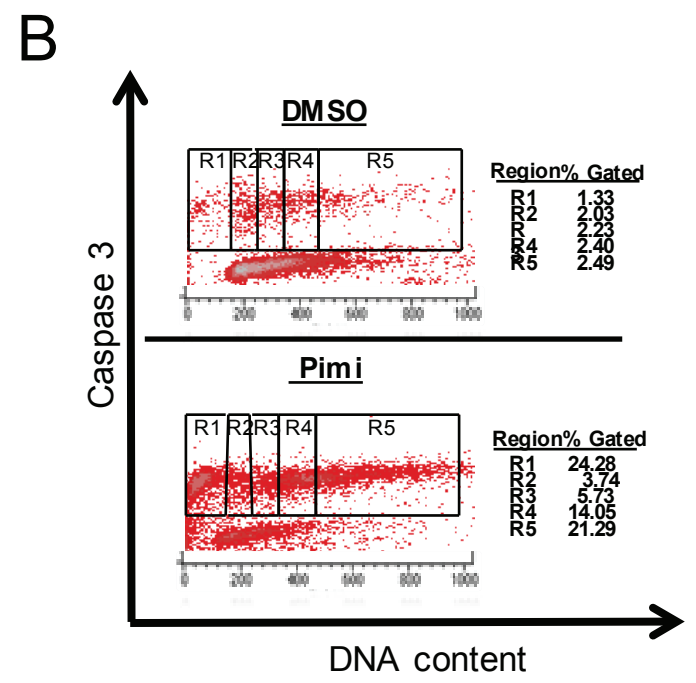

$48 \mathrm{~h}$ treatment

DMSO 1:1000

Pim i, $10 \mu M$
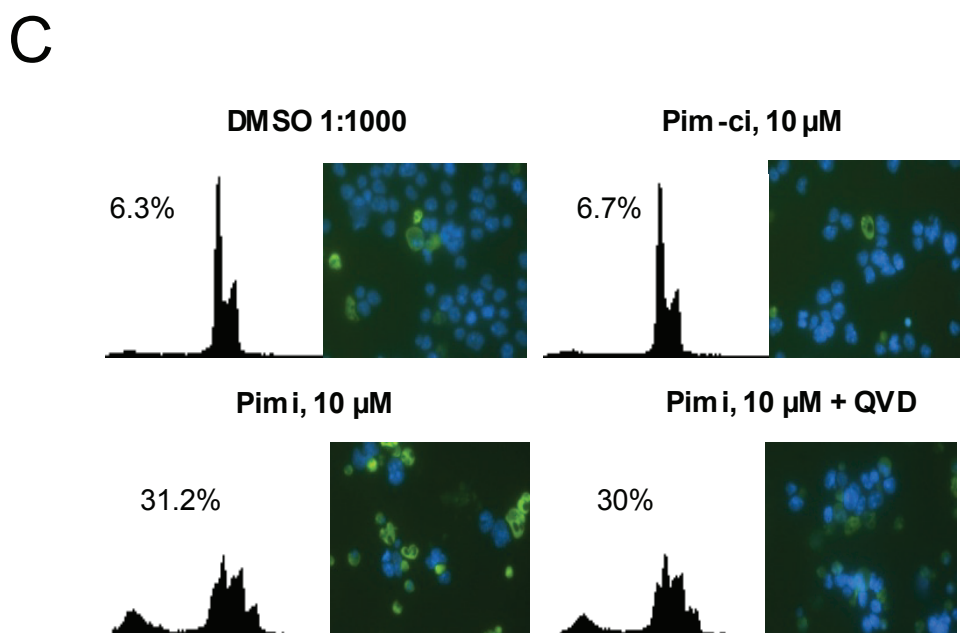

Figure 4: Pimi induces cleavage of caspase-3 in G2/M and aneuploid cells but cell death is not blocked by pan-caspase inhibition. A) E 4239 cells cultured in the presence of DMSO, Pim-ci or Pimi was harvested at indicated timepoints and divided into two subsets. One set was stained with propidium iodide (PI) for FACS analysis and the other set was cytospun onto glass slides, labeled with cleaved caspase- 3 antibody and a FITC-secondary antibody and then subjected to immunofluorescense analysis as described in materials and methods. B) Pimi treated E $\mu 239$ cells were fixed and intracellularly labeled with cleaved caspase-3 antibody and 7-amino actinomycin D (7AAD). Cells were analyzed by FACS for quantification of the cleaved caspase-3 signal related to each phase of the cell cycle. C) Cells co-treated for 48 hours with either DMSO, Pim-ci or Pimi and $20 \mu \mathrm{M}$ of the pan-caspase inhibitor QVD-OPH were harvested and stained with propidium iodide (PI) and analyzed by FACS as well as cytospun onto glass slides, labeled with cleaved caspase-3 and analyzed by immunofluorescence. 
Pim kinases are constitutively active and protein levels are mainly regulated through transcriptional activation and proteosomal degradation $[21,78]$, our finding that Pim-3 is regulated by Myc represents a significant addition to our understanding of Pim-3 regulation. It may also constitute an example of a feed-forward loop, since Pim-3 recently was shown to stabilize c-Myc [79]. This could offer an alternative explanation to why Myc's transcriptional activity is decreased by Pimi-treatment in E $\mu 239$ cells.

New targeted therapies are needed [80] and inhibition of Pim kinases has evoked a lot of interest but thus far no inhibitor has been granted approval for clinical use. Here we show that Myc-induced B cell lymphomas are sensitive to a new Pim kinase inhibitor generated at Abbott Laboratories, Pimi [63]. Whether or not Pim-3 is the sole target whose inhibition is the cause of the observed effect is not formally proven since RNAi against Pim 3 yielded incomplete and thereby inconclusive knockdown data (not shown). Nevertheless, Pimi induces cell death that correlates with but may be independent of caspase-3 activation. The reason why we cannot exclude caspase-dependent death is that there is a debate whether or not complete caspase inhibition is achievable pharmacologically [81]. Here we observe a considerable reduction in cleaved caspase-3 with QVD-OPH but the remaining amount may be sufficient to trigger death. If it is not classical caspase-dependent apoptosis then autophagy and/or programmed necrosis are candidate mechanisms. Indeed, autophagy was recently shown to be triggered by Pim-3 inhibition [79]. Given that Myc regulates metabolism [82] it would be plausible that interference with Myc's transcriptional function would induce major changes in tumor cell metabolism that could result in apoptosis, autophagy and/or necrosis.

\section{MATERIALS AND METHODS}

\section{Reagents}

Primary antibodies were obtained from Cell Signaling (Pim-3 (D17C9), pBad (Ser112, 40A9), Myc (D84C12), p4E-BP1 (Thr37/46), and Caspase-3 (Asp175)), Santa Cruz (Pim-1(12H8), Pim-2(1D12), and Myc (N262)), Abcam (Pim-3) and Sigma ( $\beta$-actin). Horseradish peroxidase-conjugated antibodies against mouse and rabbit antibodies were from GE Healthcare Life Sciences. The pan-caspase inhibitor Q-VD-OPH was obtained from Biovision. The Pim inhibitor, Pimi (2-Dimethylaminomethyl-8-(4-hydroxy-phenyl)-3Hbenzo[4,5]thieno[3,2-d]pyrimidin-4-one), and the nonactive control substance, Pim-ci, were obtained from Abbott Laboratories.

\section{Cell culture}

NIH 3T3 fibroblasts were purchased from American Type Culture Collection and where cultured in Dulbecco's Modified Eagle Medium supplemented with $10 \%$ fetal calf serum FCS, 2 mM L-Glutamine, 1 $\mathrm{mM}$ sodium pyruvate and $1 \mathrm{x}$ antibiotic-antimycotic cocktail (penicillin/streptomycin/fungizone; Invitrogen). Human lymphoma cell lines P493-6 (a kind gift from Dr. Georg Bornkamm), human Burkitt Lymphoma cell lines; Akata, BJAB, Daudi, DG75, Louckes, P3HR1, Raji, Raji-EBNA6 and mouse lymphoma cell lines established from tumors arising in either $\lambda-M y c$ or $E \mu-M y c$ transgenic mice [29, 83] were cultivated in RPMI1640 medium supplemented with $10 \%$ FCS, 2 mM L-glutamine, $50 \mu \mathrm{M}$ $\beta$-mercaptoethanol, $0.1875 \%$ sodium bicarbonate and 50 $\mu \mathrm{g} / \mathrm{ml}$ gentamicin. For Myc-ER experiments cells were grown in the presence or absence of 4-hydroxytamoxifen (4-HT) and/or cycloheximide (both from Sigma) for $4 \mathrm{~h}$ followed by RNA harvest and analysis.

\section{Cell cycle and apoptosis analysis}

For cell cycle analysis, suspension cells were harvested by centrifugation after which the pellet was dissolved in Vindelöv's solution (10 mM Tris, $10 \mathrm{mM}$ $\mathrm{NaCl}, 75 \mu \mathrm{M}$ propidium iodide, $0.1 \%$ Igepal and 700 units/ liter RNase adjusted to $\mathrm{pH}$ 8.0) to a final cell concentration of $1 * 10^{5}-1 * 10^{6} \mathrm{c} / \mathrm{ml}$. The cells were then analyzed in a FACScalibur flow cytometer (BD Biosciences) plotting cell cycle distribution in linear mode in the FL3 channel on the $\mathrm{x}$-axis. Apoptotic cells were analyzed as having less than a diploid genome and depicted as sub-G1 cells in a logarithmic FL-2 channel. For cleaved caspase-3 analysis, cells were fixed in 3\% paraformaldehyde-PBS and permeabilized in ice-cold $90 \%$ methanol. Incubation with primary antibody against cleaved caspase-3 (Cell signaling) was performed overnight and was followed by incubation with a FITC-conjugated secondary antibody (Dako) for $1 \mathrm{~h}$. Cells were then stained with 7-aminoactinomycin D (7AAD; Sigma) and analyzed by FACS analysis on a FACScalibur flow cytometer (BD Biosciences) using the FL1 (cleaved caspase-3) and FL2 (7-AAD) channels.

\section{Protein extraction and western blotting}

Cells and harvested lymphomas were snapfrozen in liquid nitrogen and stored at $-80{ }^{\circ} \mathrm{C}$ until further processing. Lymphomas were crushed in liquid nitrogen before addition of Tween-20 lysis buffer (50 mM Hepes, $\mathrm{pH} 7.5 / 150 \mathrm{mM} \mathrm{NaCl} / 1 \mathrm{mM}$ EDTA/2.5 mM EGTA/0.1\% Tween-20/ $1 \mathrm{mM}$ phenylmethylsulfonyl fluoride/10mM $\beta$-glycerophosphate/1mM $\quad \mathrm{NaF} / \quad 0.1 \mathrm{mM} \quad \mathrm{NaVO} 4$ supplemented with Minicomplete protease inhibitor cocktail tablets (Roche)) followed by sonication at $3 \times 7 \mathrm{sec}$ pulses in a Soniprep $150 \mathrm{MSE}, 20 \%$ power. Cell debris 
was pelleted by centrifugation at $1500 \mathrm{rpm}$ ( 5 minutes, 4 ${ }^{\circ} \mathrm{C}$ ) and supernatant was transferred to a fresh tube. Protein concentration was determined using the Bio-Rad protein determination kit. $50 \mu \mathrm{g}$ of protein samples were separated on SDS-PAGE gels and transferred to nitrocellulose membranes (Schleicher-Schuell) activated in deionized water. Membranes were stained with Ponceau S Red dye to visualize equal loading and all subsequent steps were carried out in TBS-Tween (10 mM Tris-HCl, $\mathrm{pH} 7.6$, $150 \mathrm{mM} \mathrm{NaCl}$ and $0.05 \%$ Tween-20) either containing $5 \%$ milk (blocking and antibody incubations) or $2 \%$ BSA (phosphospecific antibody incubations). Antibody binding was visualized by enhanced chemiluminescence using the SuperSignal West Dura or Pico reagents from Pierce and either an X-ray film or a LAS4000 imaging system (Fujifilm Lifescience).

\section{RNA preparation and analysis}

RNA was isolated using Trizol reagent (Invitrogen) or the NucleoSpin RNA II kit (Macherey-Nagel). Synthesis of cDNA was made with iScript first strand synthesis kit (Bio-Rad) on $1 \mu \mathrm{g}$ RNA. Quantitative PCR (qPCR) was performed using the KAPA SYBR FAST qPCR Kit (Kapa Biosystems), cDNA and primers directed against Pim1, Pim2, Pim3, Srm, Myc, Amd1, Aurkb, Cad, Shmt1, Shmt2 or $U b$ (Ubiquitin) on an iCycler iQ5 real-time PCR machine (Bio-Rad). Relative mRNA levels were calculated using the $\Delta \Delta \mathrm{CT}$ method. Primer sequences are available on request.

\section{Chromatin immunoprecipitation (ChIP)}

P493-6 cells were grown in the presence of $0.1 \mathrm{ug} /$ $\mathrm{ml}$ tetracycline (Myc off) for 72 hours after which they were cleared of dead cells by centrifugation on a Ficoll (GE healthcare) gradient. One culture was continuously cultured in the presence of tetracycline (Myc off) whereas the other culture was grown in media only (Myc on). After 8 hours aliquots from each culture were taken for protein and mRNA analysis and the rest of cells (approximately $30 * 10^{6}$ cells) where cross-linked using 1 $\%$ formaldehyde for 10 minutes. $\lambda 820$ cells were expanded in normal media to correct cell density and were then cross-linked and handled as described before. The ChIP protocol was performed according to the manufacturer's instructions (SimpleChIP enzymatic chromatin IP kit, Cell Signaling). Immunoprecipitations was performed using Myc antibodies ( $\lambda 820$ cells; D84C12, Cell Signaling, P493-6 cells; N262, SantaCruz). qPCR was run on immunoprecipitated and control chromatin using primers against E-boxes in the mouse and human Pim3 gene. Control primers were designed against a region outside the Pim3 gene. A 1:50 volume of chromatin was processed without antibody and used as total input control for quantitative PCR. Percentage total chromatin immunoprecipitated was calculated using the equation $\%$ total $=2^{(\mathrm{Ct} \text { input }-\mathrm{Ct} \mathrm{ChIP})} \times$ \% input used for chromatin immunoprecipitation (ChIP). As positive controls for Myc transcriptional regulation, primers directed against the established Myc target genes Srm and Odc were used in the ChIP assay on $\lambda 820$ cells, whereas primers against $C C N D 2$ were used for P493-6 cells. Sequences for primers are available on request.

\section{Immunofluorescence and immunohistochemistry}

Following treatment cells were harvested by cytospin onto glass slides. The cells were fixed and permeabilized with a PBS solution containing 4\% paraformaldehyde and $0.2 \%$ Triton $\mathrm{X}-100$ for 20 minutes and then washed in PBS and blocking solution (5\% FCS in PBS). After 1 hour of blocking, primary Caspase- 3 antibody in blocking solution was added, and the slides were incubated overnight at $4^{\circ} \mathrm{C}$ in a moisture chamber. The cells were washed and incubated with a fluorescein isothiocyanate (FITC)-conjugated secondary antibody and subsequently stained with Hoechst and mounted. The slides were analyzed by fluorescence microscopy.

For immunohistochemistry, 2- $\mu \mathrm{m}$ sections of lymphoma paraffin blocks were deparaffinized. Antigen retrieval was performed by pressure cooking in citrate buffer (pH6) for 7min. Primary antibodies against Pim3 (Abcam) were incubated overnight at $4^{\circ} \mathrm{C}$. Antibody detection was performed using the DAKO REAL ${ }^{\mathrm{TM}}$ detection kit (DAKO) according to the manufacturer's protocol.

\section{$\left[{ }^{3} \mathrm{H}\right]$-thymidine incorporation}

Cells were cultured in 96-well plates for $48 \mathrm{~h}$ in the presence of either DMSO or various concentrations of Pimi. The last $2 \mathrm{~h}$ of incubation, $20 \mu \mathrm{Ci}$ of $\left[{ }^{3} \mathrm{H}\right]$-thymidine (Amersham) $/ \mathrm{ml}$ media was added and the cells were harvested by a semiautomatic cell harvester (Inotech CH-5605 Dottikon). [ $\left.{ }^{3} \mathrm{H}\right]$-thymidine incorporation was measured using a liquid scintillation counter (PerkinElmer).

\section{ACKNOWLEDGEMENTS}

We thank Georg Bornkamm (Helmholtz Zentrum München, Germany) for providing P493-6 cells. We also acknowledge Abbott Laboratories (Abbott Park, IL) for providing the Pim kinase inhibitor and Dr. Joel Leverson for fruitful discussions and critical review of the manuscript.

This work was supported by the Swedish Cancer Society, the Association of International Cancer Research, The Swedish Research Council, the Kempe foundation, 
Norrland's/Lion's Cancer foundation and the Umeå University Career Grant to J.A.N, and the Deutsche Forschungsgemeinschaft SFB TRR 54 to U.K. Y.L. is a recipient of a Sweden-China Governmental Exchange scholarship from the Swedish Institute.

\section{REFERENCES}

1. Hanahan D, Weinberg RA. Hallmarks of cancer: the next generation. Cell. 2011; 144:646-674.

2. Askew DS, Ashmun RA, Simmons BC, Cleveland JL. Constitutive c-myc expression in an IL-3-dependent myeloid cell line suppresses cell cycle arrest and accelerates apoptosis. Oncogene. 1991; 6:1915-1922.

3. Evan GI, Wyllie AH, Gilbert CS, Littlewood TD, Land H, Brooks M, Waters CM, Penn LZ, Hancock DC. Induction of apoptosis in fibroblasts by c-myc protein. Cell. 1992; 69:119-128.

4. Nilsson JA, Cleveland JL. Myc pathways provoking cell suicide and cancer. Oncogene. 2003; 22:9007-9021.

5. Cuypers HT, Selten G, Quint W, Zijlstra M, Maandag ER, Boelens W, van Wezenbeek P, Melief C, Berns A. Murine leukemia virus-induced T-cell lymphomagenesis: integration of proviruses in a distinct chromosomal region. Cell. 1984; 37:141-150.

6. Allen JD, Verhoeven E, Domen J, van der Valk M, Berns A. Pim-2 transgene induces lymphoid tumors, exhibiting potent synergy with c-myc. Oncogene. 1997; 15:11331141.

7. van Lohuizen M, Verbeek S, Krimpenfort P, Domen J, Saris C, Radaszkiewicz T, Berns A. Predisposition to lymphomagenesis in pim-1 transgenic mice: cooperation with c-myc and N-myc in murine leukemia virus-induced tumors. Cell. 1989; 56:673-682.

8. Wu Y, Wang YY, Nakamoto Y, Li YY, Baba T, Kaneko S, Fujii C, Mukaida N. Accelerated hepatocellular carcinoma development in mice expressing the Pim-3 transgene selectively in the liver. Oncogene. 2010; 29:2228-2237.

9. Mikkers H, Allen J, Knipscheer P, Romeijn L, Hart A, Vink E, Berns A. High-throughput retroviral tagging to identify components of specific signaling pathways in cancer. Nat Genet. 2002; 32:153-159.

10. van der Lugt NM, Domen J, Verhoeven E, Linders K, van der Gulden H, Allen J, Berns A. Proviral tagging in E mumyc transgenic mice lacking the Pim-1 proto-oncogene leads to compensatory activation of Pim-2. EMBO J. 1995; 14:2536-2544.

11. Verbeek S, van Lohuizen M, van der Valk M, Domen J, Kraal G, Berns A. Mice bearing the E mu-myc and E mupim-1 transgenes develop pre-B-cell leukemia prenatally. Mol Cell Biol. 1991; 11:1176-1179.

12. Mikkers H, Nawijn M, Allen J, Brouwers C, Verhoeven E, Jonkers J, Berns A. Mice deficient for all PIM kinases display reduced body size and impaired responses to hematopoietic growth factors. Mol Cell Biol. 2004; 24:6104-6115.

13. Gapter LA, Magnuson NS, Ng KY, Hosick HL. Pim-1 kinase expression during murine mammary development. Biochem Biophys Res Commun. 2006; 345:989-997.

14. Morishita D, Katayama R, Sekimizu K, Tsuruo T, Fujita N. Pim kinases promote cell cycle progression by phosphorylating and down-regulating p27Kip1 at the transcriptional and posttranscriptional levels. Cancer Res. 2008; 68:5076-5085.

15. Wang Z, Bhattacharya N, Mixter PF, Wei W, Sedivy J, Magnuson NS. Phosphorylation of the cell cycle inhibitor p21Cip1/WAF1 by Pim-1 kinase. Biochim Biophys Acta. 2002; 1593:45-55.

16. Bachmann M, Kosan C, Xing PX, Montenarh M, Hoffmann I, Moroy T. The oncogenic serine/threonine kinase Pim1 directly phosphorylates and activates the G2/M specific phosphatase Cdc25C. Int J Biochem Cell Biol. 2006; 38:430-443.

17. Mochizuki T, Kitanaka C, Noguchi K, Muramatsu T, Asai A, Kuchino Y. Physical and functional interactions between Pim-1 kinase and Cdc25A phosphatase. Implications for the Pim-1-mediated activation of the c-Myc signaling pathway. J Biol Chem. 1999; 274:18659-18666.

18. Chen XP, Losman JA, Cowan S, Donahue E, Fay S, Vuong BQ, Nawijn MC, Capece D, Cohan VL, Rothman P. Pim serine/threonine kinases regulate the stability of Socs-1 protein. Proc Natl Acad Sci U S A. 2002; 99:2175-2180.

19. Peltola KJ, Paukku K, Aho TL, Ruuska M, Silvennoinen O, Koskinen PJ. Pim-1 kinase inhibits STAT5-dependent transcription via its interactions with SOCS1 and SOCS3. Blood. 2004; 103:3744-3750.

20. Peng C, Knebel A, Morrice NA, Li X, Barringer K, Li J, Jakes S, Werneburg B, Wang L. Pim kinase substrate identification and specificity. J Biochem. 2007; 141:353362.

21. Fox CJ, Hammerman PS, Cinalli RM, Master SR, Chodosh LA, Thompson CB. The serine/threonine kinase Pim-2 is a transcriptionally regulated apoptotic inhibitor. Genes Dev. 2003; 17:1841-1854.

22. Aho TL, Sandholm J, Peltola KJ, Mankonen HP, Lilly M, Koskinen PJ. Pim-1 kinase promotes inactivation of the pro-apoptotic Bad protein by phosphorylating it on the Ser112 gatekeeper site. FEBS Lett. 2004; 571:43-49.

23. Macdonald A, Campbell DG, Toth R, McLauchlan H, Hastie CJ, Arthur JS. Pim kinases phosphorylate multiple sites on Bad and promote 14-3-3 binding and dissociation from Bcl-XL. BMC Cell Biol. 2006; 7:1.

24. Yan B, Zemskova M, Holder S, Chin V, Kraft A, Koskinen PJ, Lilly M. The PIM-2 kinase phosphorylates BAD on serine 112 and reverses BAD-induced cell death. J Biol Chem. 2003; 278:45358-45367.

25. Zhang Y, Wang Z, Li X, Magnuson NS. Pim kinasedependent inhibition of c-Myc degradation. Oncogene. 
2008; 27:4809-4819.

26. Winn LM, Lei W, Ness SA. Pim-1 phosphorylates the DNA binding domain of c-Myb. Cell Cycle. 2003; 2:258262.

27. Aho TL, Sandholm J, Peltola KJ, Ito Y, Koskinen PJ. Pim-1 kinase phosphorylates RUNX family transcription factors and enhances their activity. BMC Cell Biol. 2006; 7:21.

28. Zippo A, De Robertis A, Serafini R, Oliviero S. PIM1dependent phosphorylation of histone $\mathrm{H} 3$ at serine 10 is required for MYC-dependent transcriptional activation and oncogenic transformation. Nat Cell Biol. 2007; 9:932-944.

29. Kovalchuk AL, Qi CF, Torrey TA, Taddesse-Heath L, Feigenbaum L, Park SS, Gerbitz A, Klobeck G, Hoertnagel K, Polack A, Bornkamm GW, Janz S, Morse HC, 3rd. Burkitt lymphoma in the mouse. J Exp Med. 2000; 192:1183-1190.

30. Mainwaring LA, Bhatia B, Kenney AM. Myc on my mind: a transcription factor family's essential role in brain development. Oncotarget. 2010; 1:86-88.

31. Alex R, Sozeri O, Meyer S, Dildrop R. Determination of the DNA sequence recognized by the bHLH-zip domain of the N-Myc protein. Nucleic Acids Res. 1992; 20:22572263.

32. Berberich S, Hyde-DeRuyscher N, Espenshade P, Cole M. max encodes a sequence-specific DNA-binding protein and is not regulated by serum growth factors. Oncogene. 1992; 7:775-779.

33. Blackwell TK, Huang J, Ma A, Kretzner L, Alt FW, Eisenman RN, Weintraub H. Binding of myc proteins to canonical and noncanonical DNA sequences. Mol Cell Biol. 1993; 13:5216-5224.

34. Blackwell TK, Kretzner L, Blackwood EM, Eisenman $\mathrm{RN}$, Weintraub H. Sequence-specific DNA binding by the c-Myc protein. Science. 1990; 250:1149-1151.

35. Kato GJ, Wechsler DS, Dang CV. DNA binding by the Myc oncoproteins. Cancer Treat Res. 1992; 63:313-325.

36. Ma A, Moroy $\mathrm{T}$, Collum R, Weintraub H, Alt FW, Blackwell TK. DNA binding by N- and L-Myc proteins. Oncogene. 1993; 8:1093-1098.

37. Papoulas O, Williams NG, Kingston RE. DNA binding activities of c-Myc purified from eukaryotic cells. J Biol Chem. 1992; 267:10470-10480.

38. Höglund A, Nilsson LM, Forshell LP, Maclean KH, Nilsson JA. Myc sensitizes p53-deficient cancer cells to the DNAdamaging effects of the DNA methyltransferase inhibitor decitabine. Blood. 2009; 113:4281-4288.

39. Forshell TP, Rimpi S, Nilsson JA. Chemoprevention of B-cell lymphomas by inhibition of the Myc target spermidine synthase. Cancer Prev Res (Phila Pa). 2010; 3:140-147.

40. Nilsson JA, Maclean KH, Keller UB, Pendeville H, Baudino TA, Cleveland JL. Mnt loss triggers Myc transcription targets, proliferation, apoptosis, and transformation. Mol Cell Biol. 2004; 24:1560-1569.
41. Pajic A, Spitkovsky D, Christoph B, Kempkes B, Schuhmacher M, Staege MS, Brielmeier M, Ellwart J, Kohlhuber F, Bornkamm GW, Polack A, Eick D. Cell cycle activation by c-myc in a burkitt lymphoma model cell line. Int J Cancer. 2000; 87:787-793.

42. Bouchard C, Dittrich O, Kiermaier A, Dohmann K, Menkel A, Eilers M, Luscher B. Regulation of cyclin D2 gene expression by the Myc/Max/Mad network: Myc-dependent TRRAP recruitment and histone acetylation at the cyclin D2 promoter. Genes Dev. 2001; 15:2042-2047.

43. Bouchard C, Thieke K, Maier A, Saffrich R, Hanley-Hyde J, Ansorge W, Reed S, Sicinski P, Bartek J, Eilers M. Direct induction of cyclin D2 by Myc contributes to cell cycle progression and sequestration of p27. Embo J. 1999; 18:5321-5333.

44. Fernandez PC, Frank SR, Wang L, Schroeder M, Liu S, Greene J, Cocito A, Amati B. Genomic targets of the human c-Myc protein. Genes Dev. 2003; 17:1115-1129.

45. Alizadeh AA, Staudt LM. Genomic-scale gene expression profiling of normal and malignant immune cells. Curr Opin Immunol. 2000; 12:219-225.

46. Ayala GE, Dai H, Ittmann M, Li R, Powell M, Frolov A, Wheeler TM, Thompson TC, Rowley D. Growth and survival mechanisms associated with perineural invasion in prostate cancer. Cancer Res. 2004; 64:6082-6090.

47. Beier UH, Weise JB, Laudien M, Sauerwein H, Gorogh T. Overexpression of Pim-1 in head and neck squamous cell carcinomas. Int J Oncol. 2007; 30:1381-1387.

48. Chen CN, Lin JJ, Chen JJ, Lee PH, Yang CY, Kuo ML, Chang KJ, Hsieh FJ. Gene expression profile predicts patient survival of gastric cancer after surgical resection. J Clin Oncol. 2005; 23:7286-7295.

49. Dai H, Li R, Wheeler T, Diaz de Vivar A, Frolov A, Tahir S, Agoulnik I, Thompson T, Rowley D, Ayala G. Pim2 upregulation: biological implications associated with disease progression and perinueral invasion in prostate cancer. Prostate. 2005; 65:276-286.

50. Dave SS, Fu K, Wright GW, Lam LT, Kluin P, Boerma EJ, Greiner TC, Weisenburger DD, Rosenwald A, Ott G, Muller-Hermelink HK, Gascoyne RD, Delabie J, Rimsza LM, Braziel RM, Grogan TM et al. Molecular diagnosis of Burkitt's lymphoma. N Engl J Med. 2006; 354:2431-2442.

51. de Vos S, Krug U, Hofmann WK, Pinkus GS, Swerdlow SH, Wachsman W, Grogan TM, Said JW, Koeffler HP. Cell cycle alterations in the blastoid variant of mantle cell lymphoma (MCL-BV) as detected by gene expression profiling of mantle cell lymphoma (MCL) and MCL-BV. Diagn Mol Pathol. 2003; 12:35-43.

52. Hsi ED, Jung SH, Lai R, Johnson JL, Cook JR, Jones D, Devos S, Cheson BD, Damon LE, Said J. Ki67 and PIM1 expression predict outcome in mantle cell lymphoma treated with high dose therapy, stem cell transplantation and rituximab: a Cancer and Leukemia Group B 59909 correlative science study. Leuk Lymphoma. 2008; 49:2081- 
2090.

53. Peltola K, Hollmen M, Maula SM, Rainio E, Ristamaki R, Luukkaa M, Sandholm J, Sundvall M, Elenius K, Koskinen PJ, Grenman R, Jalkanen S. Pim-1 kinase expression predicts radiation response in squamocellular carcinoma of head and neck and is under the control of epidermal growth factor receptor. Neoplasia. 2009; 11:629-636.

54. Poulsen CB, Borup R, Nielsen FC, Borregaard N, Hansen M, Gronbaek K, Moller MB, Ralfkiaer E. Microarraybased classification of diffuse large B-cell lymphoma. Eur J Haematol. 2005; 74:453-465.

55. Rossi D, Berra E, Cerri M, Deambrogi C, Barbieri C, Franceschetti S, Lunghi M, Conconi A, Paulli M, Matolcsy A, Pasqualucci L, Capello D, Gaidano G. Aberrant somatic hypermutation in transformation of follicular lymphoma and chronic lymphocytic leukemia to diffuse large B-cell lymphoma. Haematologica. 2006; 91:1405-1409.

56. Warnecke-Eberz U, Bollschweiler E, Drebber U, Metzger R, Baldus SE, Holscher AH, Monig S. Prognostic impact of protein overexpression of the proto-oncogene PIM-1 in gastric cancer. Anticancer Res. 2009; 29:4451-4455.

57. Wright G, Tan B, Rosenwald A, Hurt EH, Wiestner A, Staudt LM. A gene expression-based method to diagnose clinically distinct subgroups of diffuse large B cell lymphoma. Proc Natl Acad Sci U S A. 2003; 100:99919996.

58. Zheng HC, Tsuneyama K, Takahashi H, Miwa S, Sugiyama T, Popivanova BK, Fujii C, Nomoto K, Mukaida N, Takano Y. Aberrant Pim-3 expression is involved in gastric adenoma-adenocarcinoma sequence and cancer progression. J Cancer Res Clin Oncol. 2008; 134:481-488.

59. Behan JW, Yun JP, Proektor MP, Ehsanipour EA, Arutyunyan A, Moses AS, Avramis VI, Louie SG, Butturini A, Heisterkamp N, Mittelman SD. Adipocytes impair leukemia treatment in mice. Cancer Res. 2009; 69:78677874 .

60. Chen J, Kobayashi M, Darmanin S, Qiao Y, Gully C, Zhao R, Yeung SC, Lee MH. Pim-1 plays a pivotal role in hypoxia-induced chemoresistance. Oncogene. 2009; 28:2581-2592.

61. Mumenthaler SM, Ng PY, Hodge A, Bearss D, Berk G, Kanekal S, Redkar S, Taverna P, Agus DB, Jain A. Pharmacologic inhibition of Pim kinases alters prostate cancer cell growth and resensitizes chemoresistant cells to taxanes. Mol Cancer Ther. 2009; 8:2882-2893.

62. Zemskova M, Sahakian E, Bashkirova S, Lilly M. The PIM1 kinase is a critical component of a survival pathway activated by docetaxel and promotes survival of docetaxeltreated prostate cancer cells. J Biol Chem. 2008; 283:2063520644.

63. TaoZF, Hasvold LA, Leverson JD, Han EK, Guan R, Johnson EF, Stoll VS, Stewart KD, Stamper G, Soni N, Bouska JJ, Luo Y, Sowin TJ, Lin NH, Giranda VS, Rosenberg SH et al. Discovery of $3 \mathrm{H}$-benzo[4,5]thieno[3,2-d]pyrimidin- 4-ones as potent, highly selective, and orally bioavailable inhibitors of the human protooncogene proviral insertion site in moloney murine leukemia virus (PIM) kinases. J Med Chem. 2009; 52:6621-6636.

64. den Hollander J, Rimpi S, Doherty JR, Rudelius M, Buck A, Hoellein A, Kremer M, Graf N, Scheerer M, Hall MA, Goga A, von Bubnoff N, Duyster J, Peschel C, Cleveland JL, Nilsson JA et al. Aurora kinases A and B are upregulated by Myc and are essential for maintenance of the malignant state. Blood. 2010.

65. Miltenberger RJ, Sukow KA, Farnham PJ. An E-boxmediated increase in cad transcription at the G1/S-phase boundary is suppressed by inhibitory c-Myc mutants. Mol Cell Biol. 1995; 15:2527-2535.

66. Nikiforov MA, Chandriani S, O’Connell B, Petrenko O, Kotenko I, Beavis A, Sedivy JM, Cole MD. A functional screen for Myc-responsive genes reveals serine hydroxymethyltransferase, a major source of the onecarbon unit for cell metabolism. Mol Cell Biol. 2002; 22:5793-5800.

67. Murphy DJ, Swigart LB, Israel MA, Evan GI. Id2 is dispensable for Myc-induced epidermal neoplasia. Mol Cell Biol. 2004; 24:2083-2090.

68. Nilsson JA, Nilsson LM, Keller U, Yokota Y, Boyd $\mathrm{K}$, Cleveland JL. Id2 is dispensable for myc-induced lymphomagenesis. Cancer Res. 2004; 64:7296-7301.

69. Castro A, Sengupta TK, Ruiz DC, Yang E, Ivashkiv LB. IL-4 selectively inhibits IL-2-triggered Stat5 activation, but not proliferation, in human T cells. J Immunol. 1999; 162:1261-1269.

70. Li J, Peet GW, Balzarano D, Li X, Massa P, Barton RW, Marcu KB. Novel NEMO/IkappaB kinase and NF-kappa $\mathrm{B}$ target genes at the pre-B to immature B cell transition. J Biol Chem. 2001; 276:18579-18590.

71. Matikainen S, Sareneva T, Ronni T, Lehtonen A, Koskinen PJ, Julkunen I. Interferon-alpha activates multiple STAT proteins and upregulates proliferation-associated IL2Ralpha, c-myc, and pim-1 genes in human T cells. Blood. 1999; 93:1980-1991.

72. Miura O, Miura Y, Nakamura N, Quelle FW, Witthuhn BA, Ihle JN, Aoki N. Induction of tyrosine phosphorylation of Vav and expression of Pim-1 correlates with Jak2-mediated growth signaling from the erythropoietin receptor. Blood. 1994; 84:4135-4141.

73. Shirogane T, Fukada T, Muller JM, Shima DT, Hibi M, Hirano T. Synergistic roles for Pim-1 and c-Myc in STAT3-mediated cell cycle progression and antiapoptosis. Immunity. 1999; 11:709-719.

74. Wierenga AT, Vellenga E, Schuringa JJ. Maximal STAT5induced proliferation and self-renewal at intermediate STAT5 activity levels. Mol Cell Biol. 2008; 28:6668-6680.

75. Zhu N, Ramirez LM, Lee RL, Magnuson NS, Bishop GA, Gold MR. CD40 signaling in B cells regulates the expression of the Pim-1 kinase via the NF-kappa B 
pathway. J Immunol. 2002; 168:744-754.

76. Deneen B, Welford SM, Ho T, Hernandez F, Kurland I, Denny CT. PIM3 proto-oncogene kinase is a common transcriptional target of divergent EWS/ETS oncoproteins. Mol Cell Biol. 2003; 23:3897-3908.

77. Li YY, Wu Y, Tsuneyama K, Baba T, Mukaida N. Essential contribution of Ets-1 to constitutive Pim-3 expression in human pancreatic cancer cells. Cancer Sci. 2009; 100:396404.

78. Qian KC, Wang L, Hickey ER, Studts J, Barringer K, Peng C, Kronkaitis A, Li J, White A, Mische S, Farmer B. Structural basis of constitutive activity and a unique nucleotide binding mode of human Pim-1 kinase. J Biol Chem. 2005; 280:6130-6137.

79. Beharry Z, Mahajan S, Zemskova M, Lin YW, Tholanikunnel BG, Xia Z, Smith CD, Kraft AS. The Pim protein kinases regulate energy metabolism and cell growth. Proc Natl Acad Sci U S A. 2011; 108:528-533.

80. Qiao M, Shi Q, Pardee AB. The pursuit of oncotargets through understanding defective cell regulation. Oncotarget. 2010; 1:544-551.

81. Kroemer G, Martin SJ. Caspase-independent cell death. Nat Med. 2005; 11:725-730.

82. Rimpi S, Nilsson JA. Metabolic enzymes regulated by the Myc oncogene are possible targets for chemotherapy or chemoprevention. Biochem Soc Trans. 2007; 35:305-310.

83. Adams JM, Harris AW, Pinkert CA, Corcoran LM, Alexander WS, Cory S, Palmiter RD, Brinster RL. The c-myc oncogene driven by immunoglobulin enhancers induces lymphoid malignancy in transgenic mice. Nature. $1985 ; 318: 533-538$. 